\title{
QSAR and Docking studies of Gallic acid derivatives for anticancer and Immunomodulatory activity
}

\author{
Presented by \\ Dharmendra Kumar Yadav \\ Ph.D student \\ Under the supervision of \\ Dr. Feroz Khan \\ Scientist \\ Metabolic \& Structural Biology Division \\ Central Institute of Medicinal \& Aromatic Plants \\ Lucknow, INDIA
}




\section{Objective}

- QSAR and molecular docking studies for immunomodulatory activity of gallic acid \& its derivative

QSAR model for cytotoxic activity against lungs cancer cell line (A-549) 
QSAR and molecular docking studies for immunomodulatory activity of gallic acid \& its derivative

$>$ Literature survey and retrieval of known drugs/compounds

$>$ Prepared a library for immunomodulatory activity

$>$ Minimized all the molecules and calculate the descriptors for regression analyses

$>$ Developed the mathematical multiple linear regression QSAR model for immunomodulatry activity 


\section{QSAR studies}

\section{$C=-0.156436 * K-0.00118794 * R+0.910351 * T+0.0206362 * A I-0.00834447 * A M-1.06753$}

\section{$r^{2}=0.99$}

$r^{2} \mathrm{CV}=0.96$

\section{Predicted $\log \mathbf{L D}_{\mathbf{5 0}}(\mathbf{m g} / \mathbf{k g})=-0.156436 *$ Dipole Moment (debye)}

$-0.00118794 *$ Steric Energy (kcal/mole)

$+0.910351 *$ Amide group count

$+0.0206362 * \lambda_{\text {max }}(\mathrm{UV}$-visible) $(\mathrm{nm})$ $-0.00834447 *$ Molar Refractivity

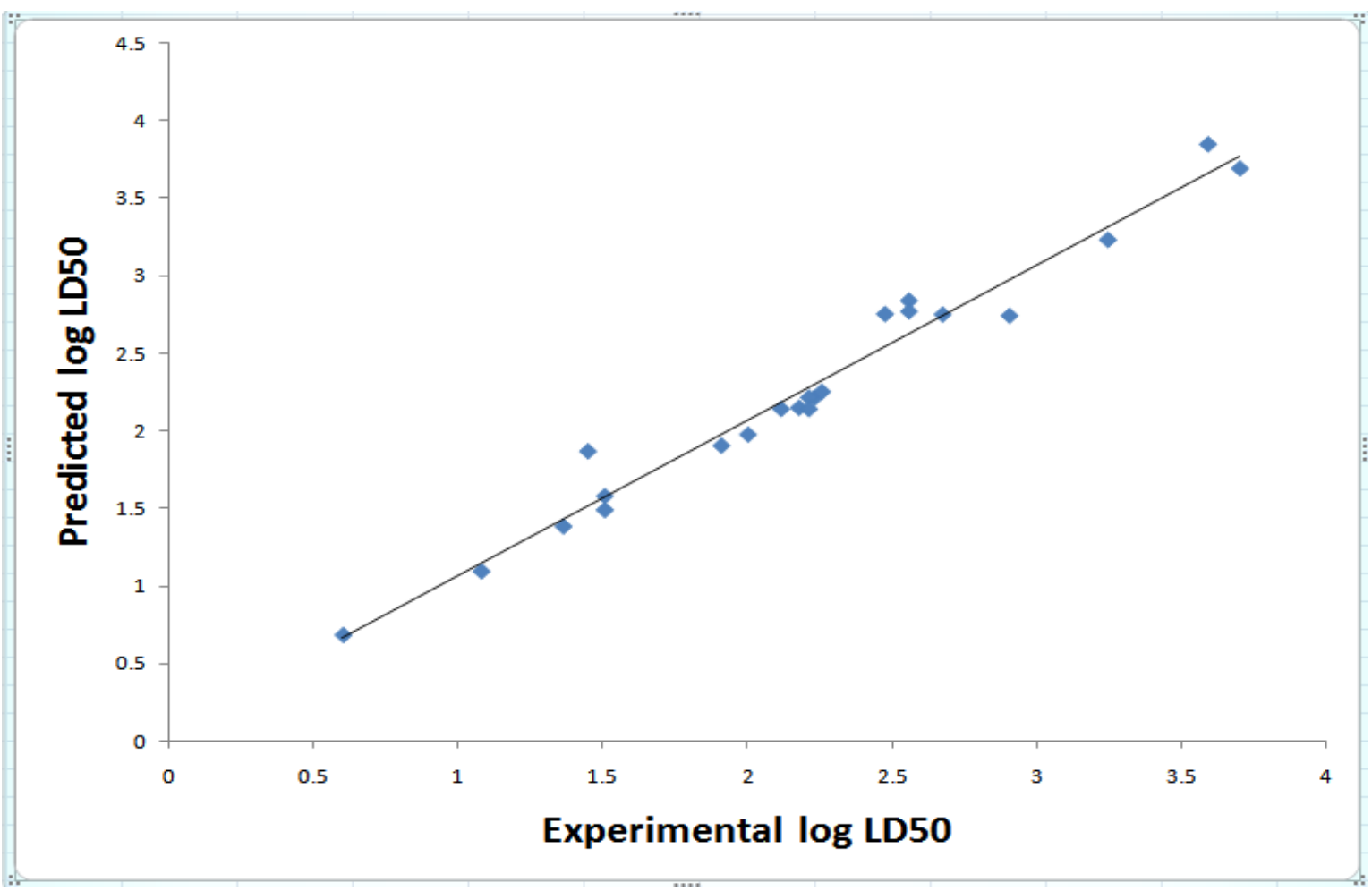

Predicted activity by the constructed model are in good with the experimental data, suggesting that these model should have a satisfactory predictive ability 
Structure of Gallic acid derivative

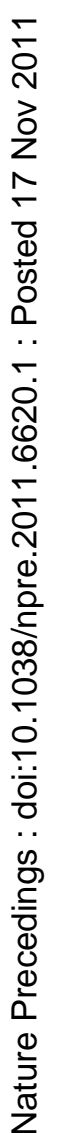
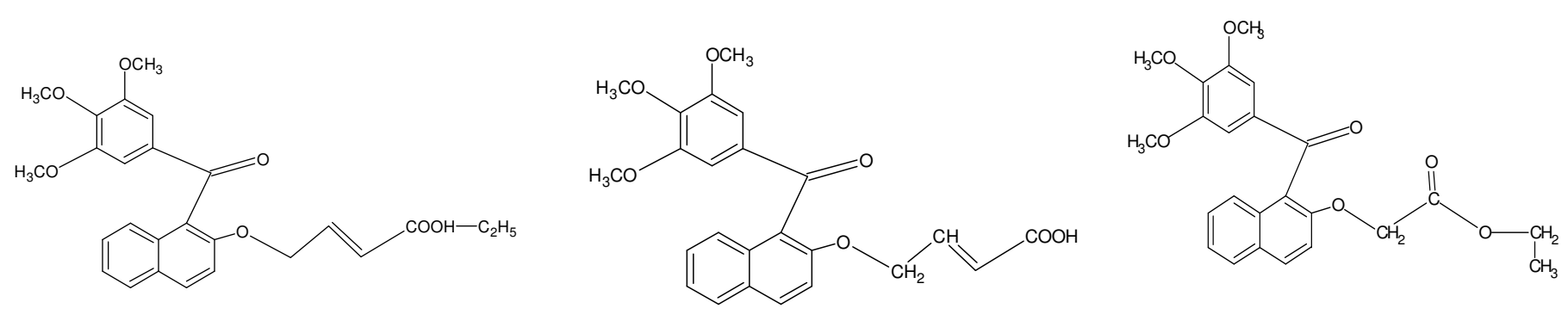

G-3

G-4

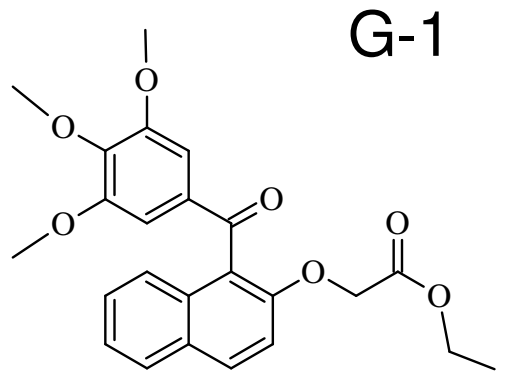

G-2
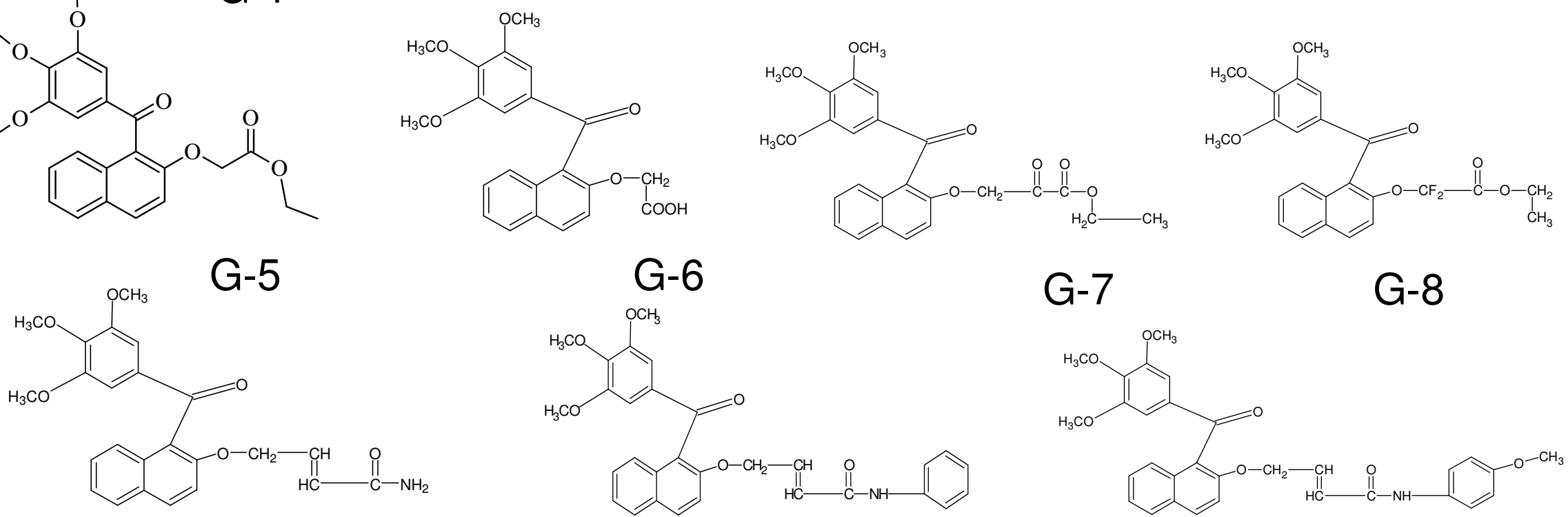

G-7

G-8

G-9

G-10
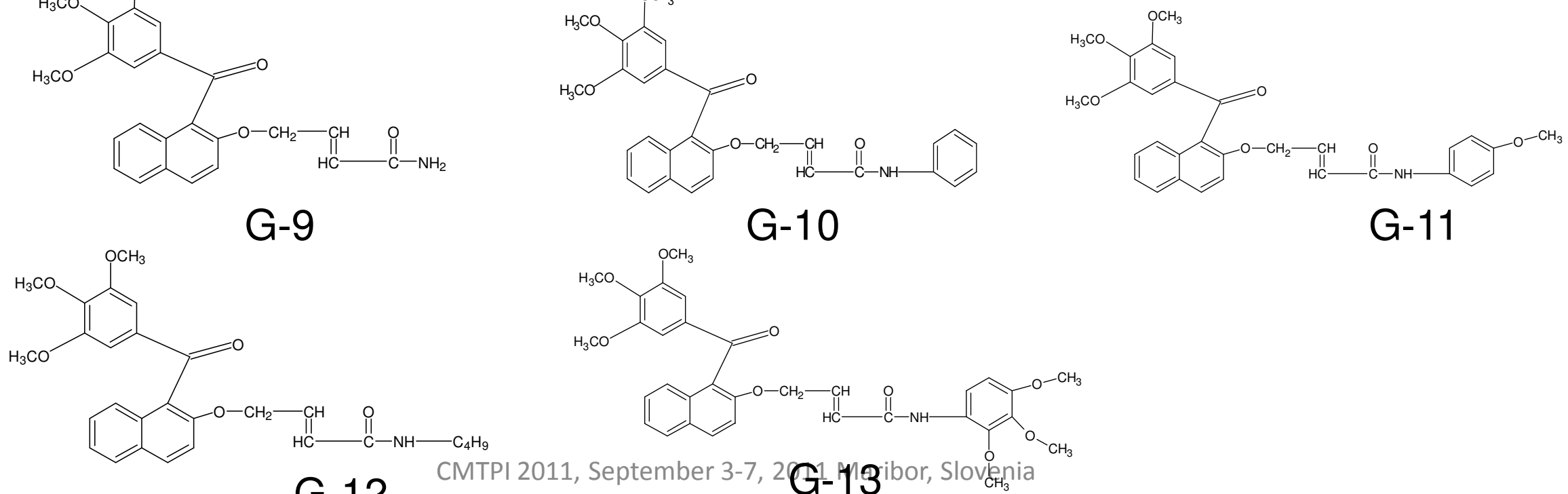

G-12

CMTPI 2011, September 3-7, 2 -11 1 ibor, Slovienia 
Predicted active immuno-modulatory compounds through derived QSAR model

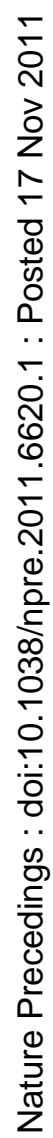

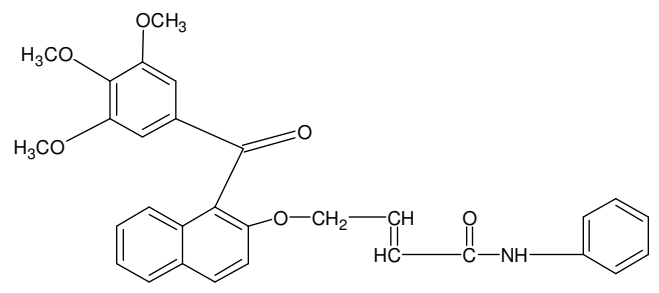

G-10 (Pred. LD $_{50}=480.84 \mathrm{mg} / \mathrm{kg}$ )

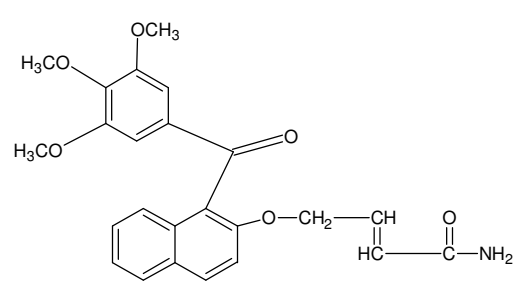

G-9 (Pred. LD $_{50}=325.84 \mathrm{mg} / \mathrm{kg}$ )

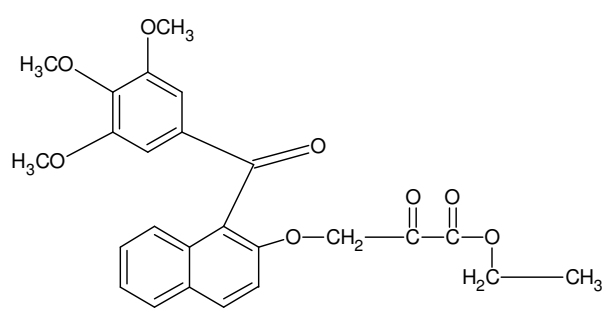

G-7 (Pred. LD ${ }_{50}=190.99 \mathrm{mg} / \mathrm{kg}$ )

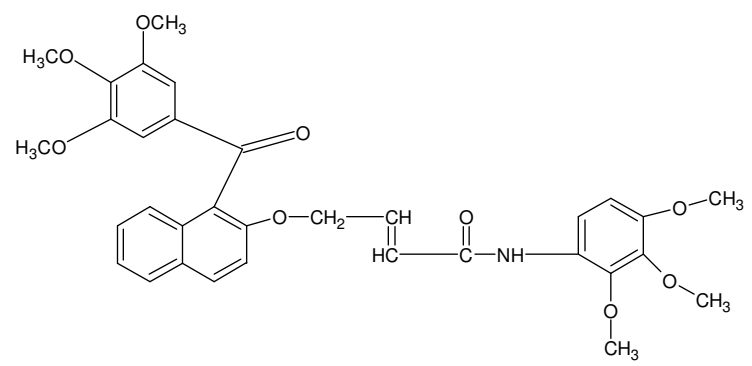

G-13 (Pred. LD $_{50}=412.1 \mathrm{mg} / \mathrm{kg}$ )

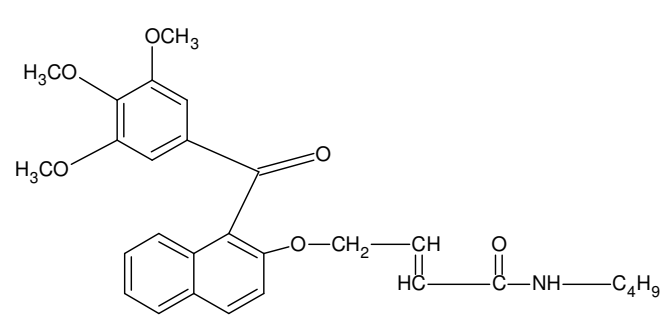

G-12 (Pred. $\left.\mathrm{LD}_{50}=311.89 \mathrm{mg} / \mathrm{kg}\right)$

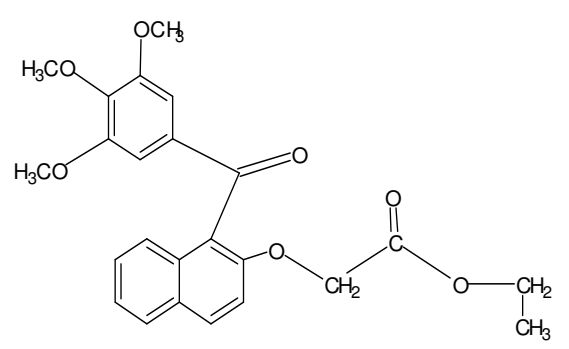

G-4 (Pred. $\mathrm{LD}_{50}=212.81 \mathrm{mg} / \mathrm{kg}$ )

CMTPI 2011, September 3-7, 2011 Maribor, Slovenia 
Binding affinity of gallic acid derivative with INF alpha2 receptor

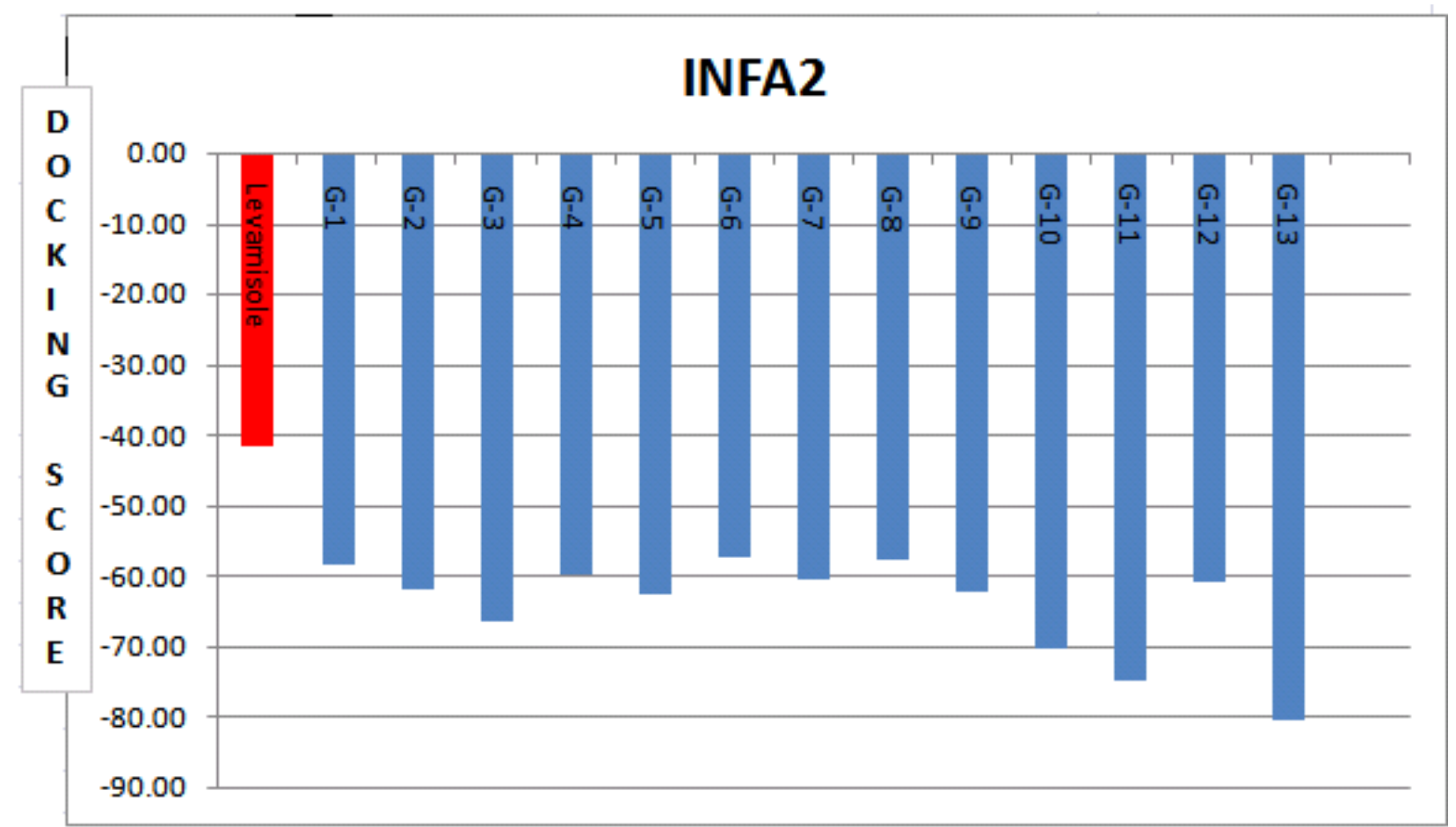




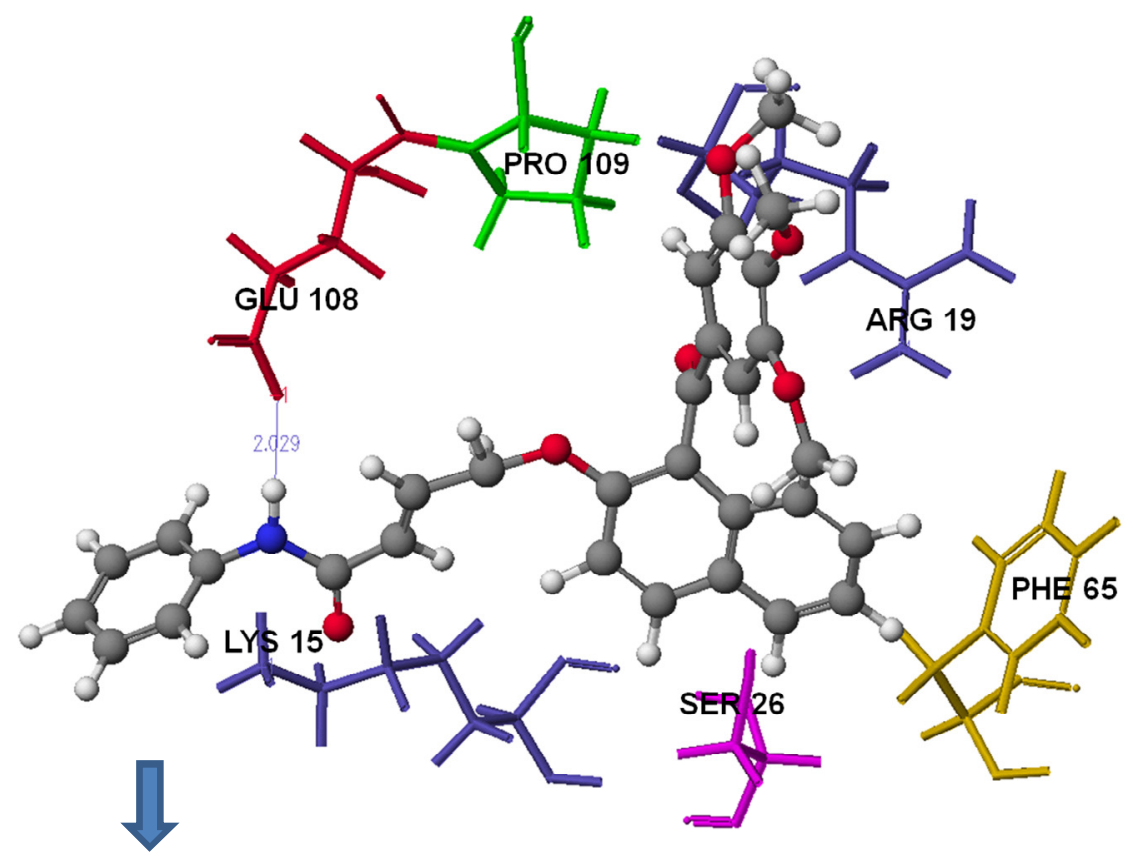

Compound G-10 docked on INFa-2 with docking energy $-70.26 \mathrm{kcal} / \mathrm{mol}$ and $\mathrm{H}$-bond of $2.029 \AA$ to binding pocket residue GLU-108

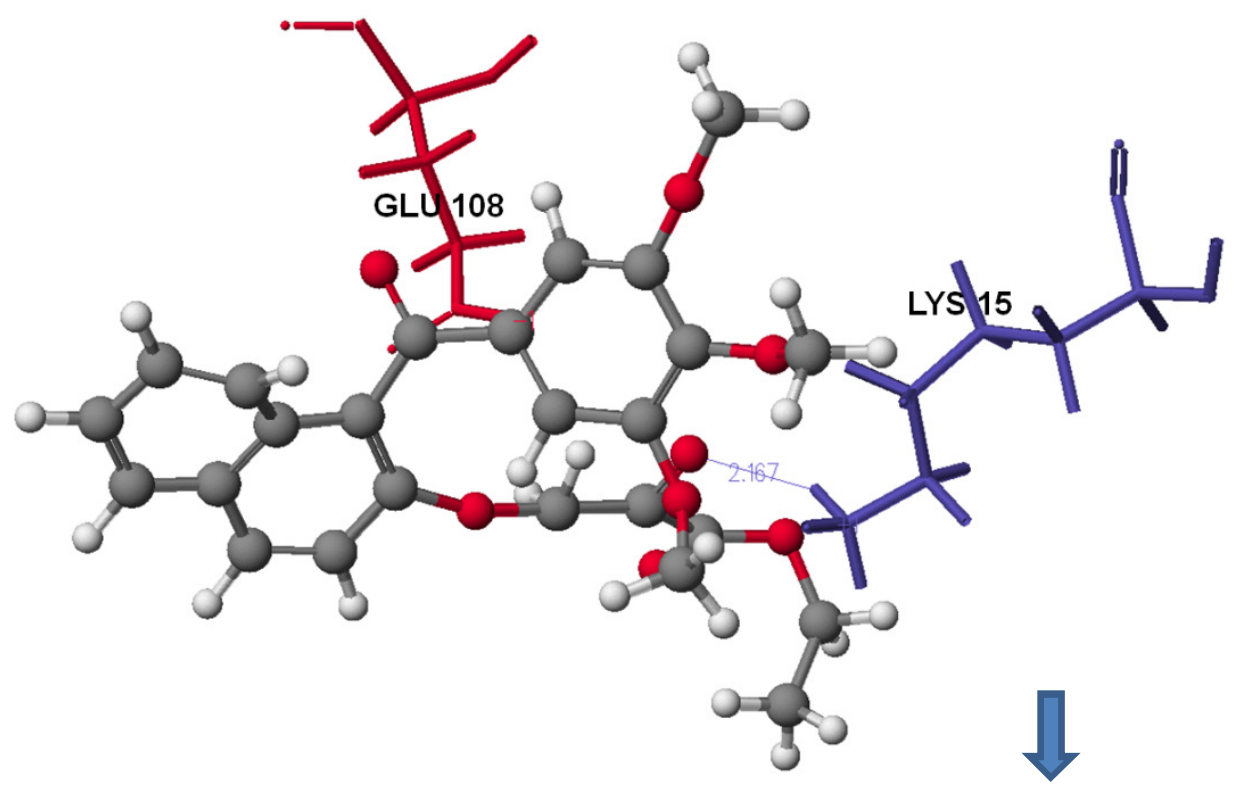

Compound G-7 docked on INFa-2 with docking energy $60.59 \mathrm{kcal} / \mathrm{mol}$ and $\mathrm{H}$-bond of $2.167 \AA$ to binding pocket residue LYS-15

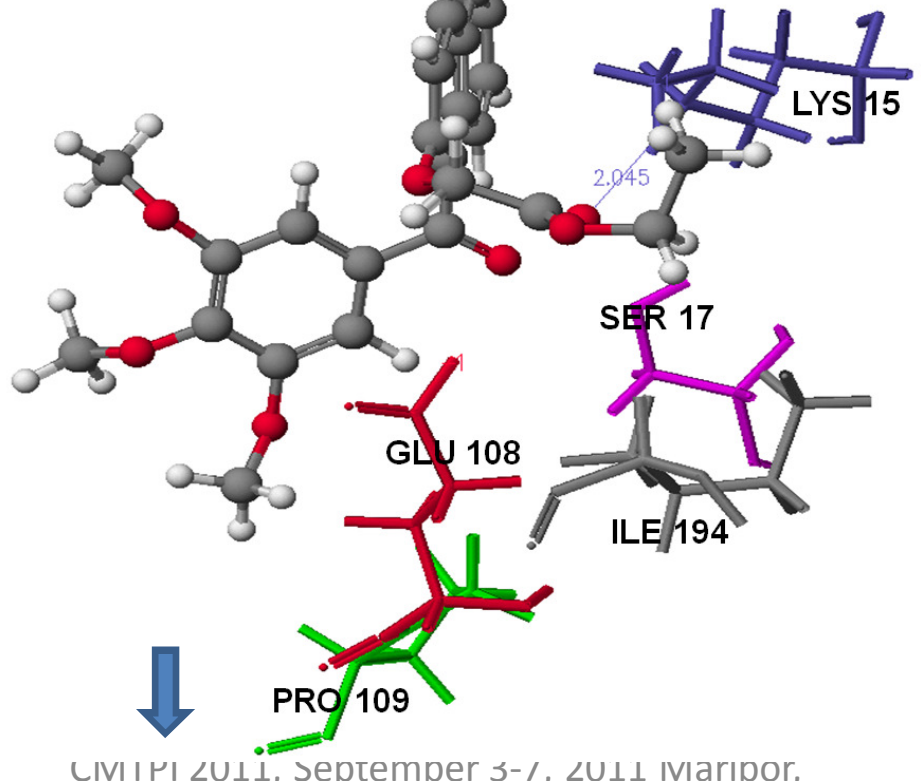

Compound G-4 docked on INFa-2 with docking energy -59.87 Keal/mol and H-bond of $2.045 \AA$ to binding pocket residue LYS-15 


\section{Binding affinity of gallic acid derivative with IL 4 receptor}

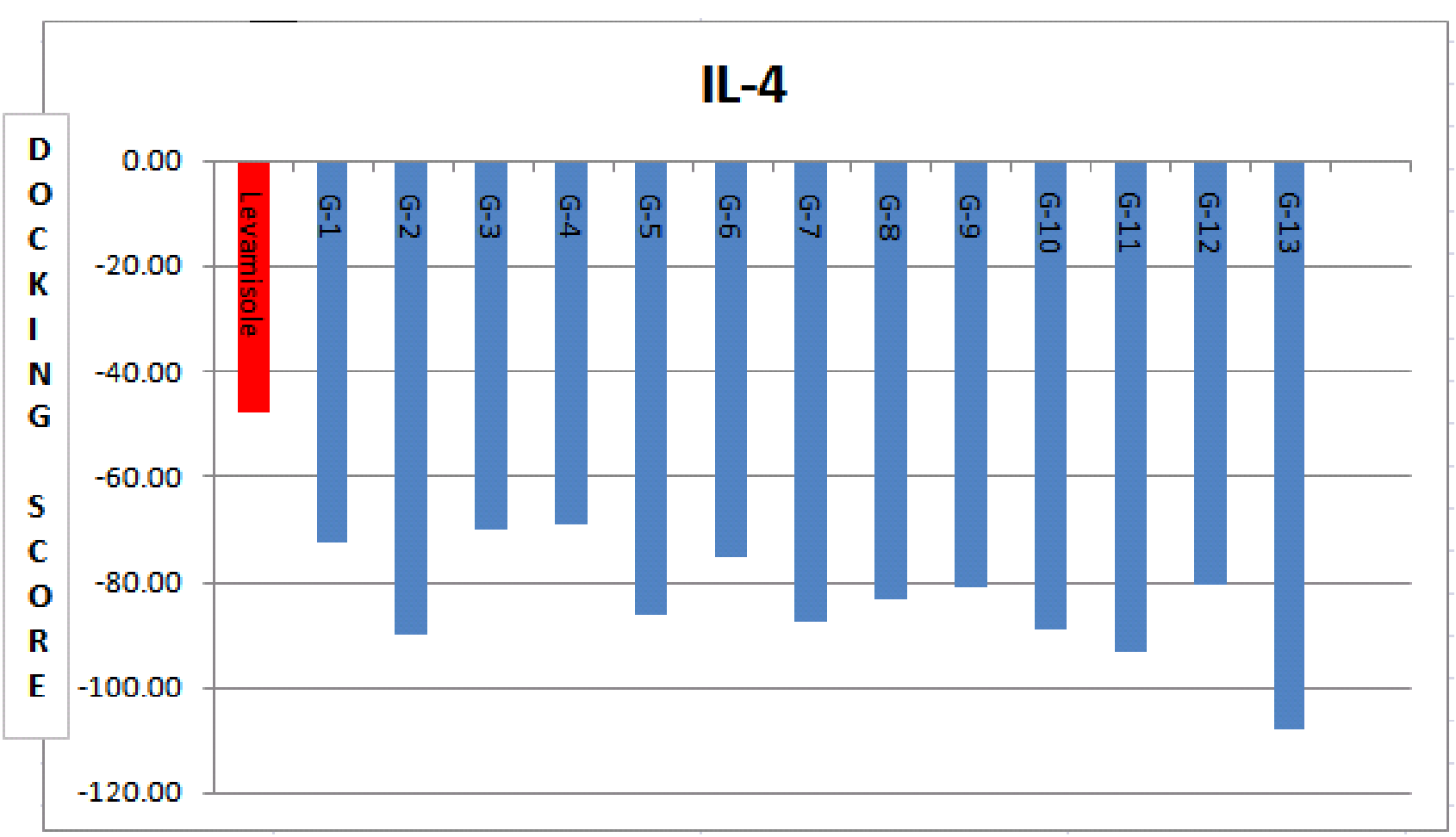


Binding affinity of gallic acid derivative with IL-6 receptor

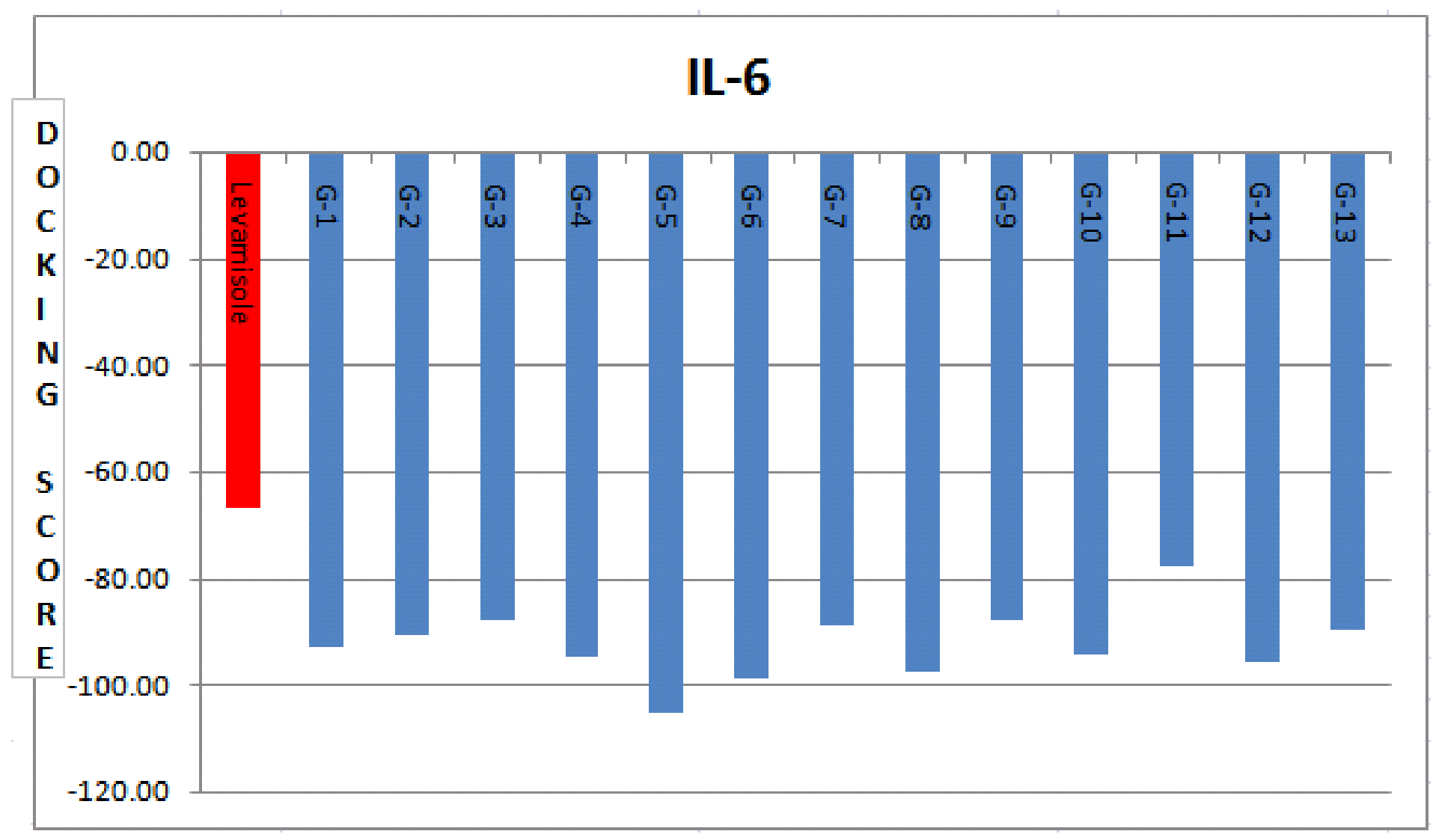




\section{Binding affinity of gallic acid derivative with IL 6 receptor}

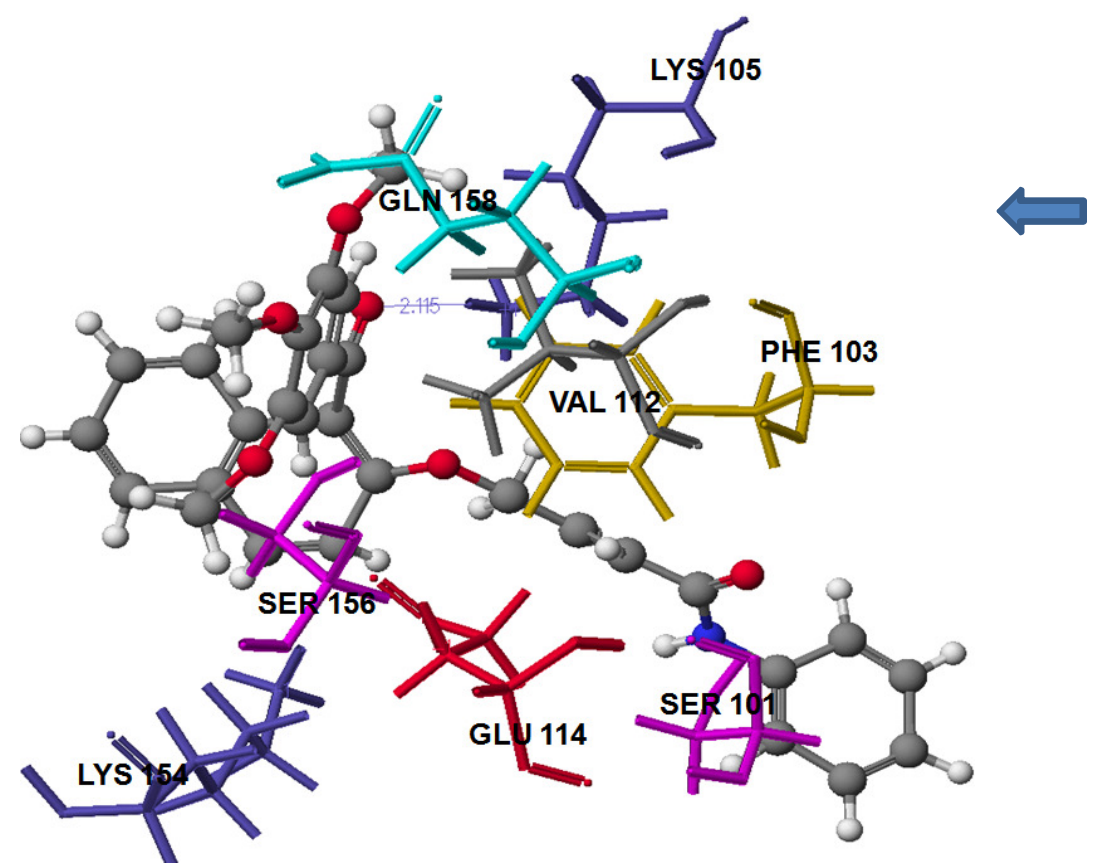

Compound G-10 docked on IL-6 with docking energy $-94.44 \mathrm{kcal} / \mathrm{mol}$ and $\mathrm{H}$-bond of $2.115 \AA$ to binding pocket residue LYS-105

Compound G-5 docked on r IL-6 with docking energy - 87.73

$\mathrm{kcal} / \mathrm{mol}$ and $\mathrm{H}$-bond of $2.075 \AA$ to binding pocket residue LYS-105

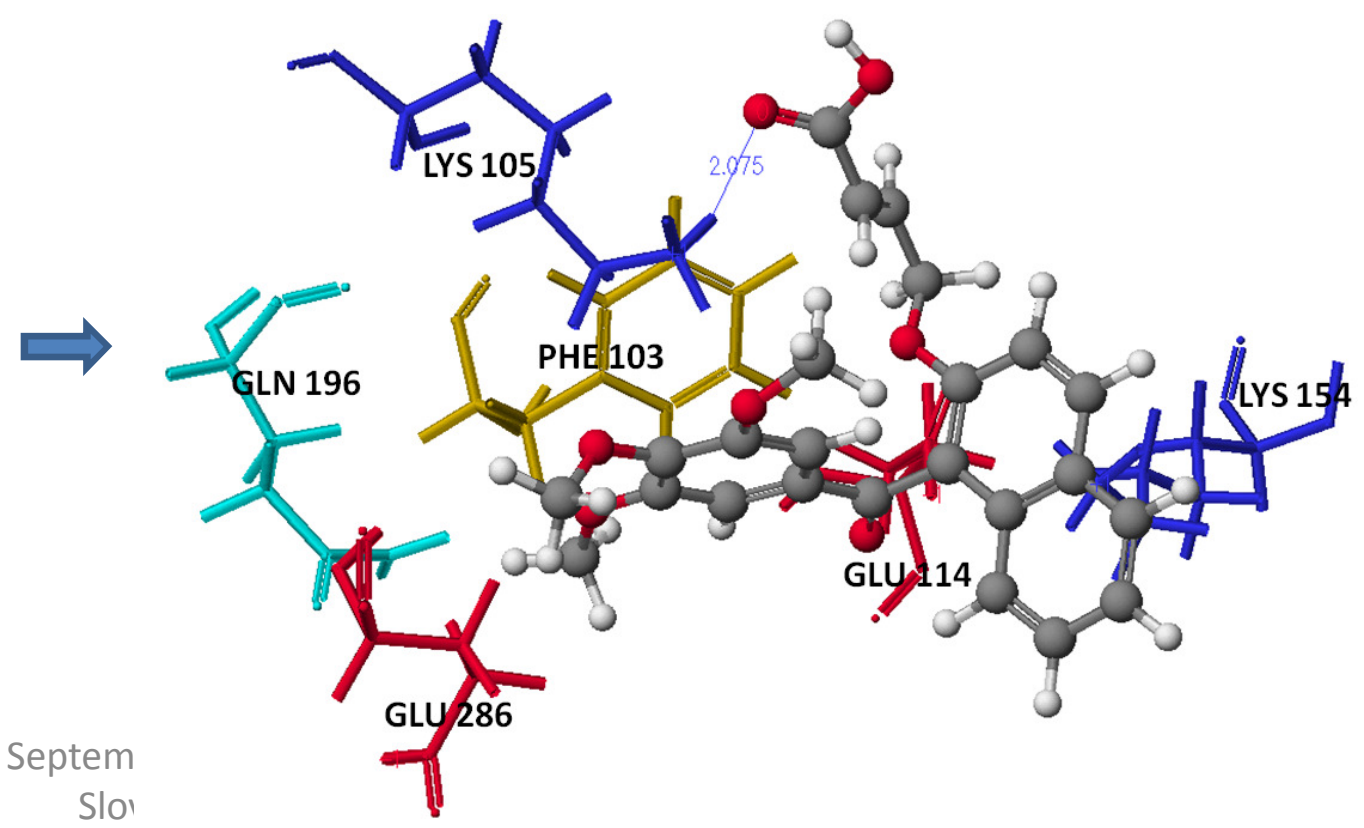




\section{Drug likeness properties of gallic acid derivative}

\begin{tabular}{|c|c|c|c|c|c|c|c|c|c|}
\hline \multirow[t]{4}{*}{ Compound } & \multicolumn{8}{|c|}{ Pharmacokinetic property (ADME) dependent on chemical descriptors } & \multirow{4}{*}{$\begin{array}{l}\text { Rule of } 5 \\
\text { violation }\end{array}$} \\
\hline & \multirow{3}{*}{$\begin{array}{l}\text { ADM } \\
\text { Oral } \\
\text { bioavailab } \\
\text { ility: } \\
\text { TPSA } \\
\left(\AA^{2}\right)\end{array}$} & \multirow{3}{*}{$\begin{array}{l}\mathrm{AE} \\
\mathrm{MW}\end{array}$} & \multirow{3}{*}{$\frac{\mathrm{ADME}}{\log \mathrm{P}}$} & \multicolumn{5}{|c|}{$\mathrm{AD}$} & \\
\hline & & & & \multicolumn{3}{|c|}{ H-bond donor } & \multicolumn{2}{|c|}{ H-bond acceptor } & \\
\hline & & & & $\begin{array}{l}\text { Amine } \\
\text { group } \\
\text { count }\end{array}$ & $\begin{array}{l}\text { Sec- } \\
\text { amine } \\
\text { group } \\
\text { count }\end{array}$ & $\begin{array}{l}\text { Hydroxyl } \\
\text { group } \\
\text { count }\end{array}$ & $\begin{array}{l}\text { Nitrogen } \\
\text { atom } \\
\text { count }\end{array}$ & $\begin{array}{l}\text { Oxygen } \\
\text { atom } \\
\text { count }\end{array}$ & \\
\hline Levamisol & 40.9 & 204.29 & 3.259 & 0 & 0 & 0 & 2 & 0 & 0 \\
\hline G-1 & 64.99 & 338.35 & 3.228 & 0 & 0 & 1 & 0 & 5 & 0 \\
\hline G-2 & 53.99 & 450.48 & 3.832 & 0 & 0 & 0 & 0 & 7 & 0 \\
\hline G-3 & 91.29 & 424.44 & 3.243 & 0 & 0 & 2 & 0 & 7 & 0 \\
\hline G-4\# & 80.29 & 424.44 & 3.175 & 0 & 0 & 0 & 0 & 7 & 0 \\
\hline G-5 & 91.29 & 396.39 & 2.801 & 0 & 0 & 0 & 0 & 7 & 0 \\
\hline G-6 & 80.29 & 438.47 & 3.357 & 0 & 0 & 0 & 0 & 7 & 0 \\
\hline G-7\# & 97.36 & 452.46 & 2.712 & 0 & 0 & 0 & 0 & 8 & 0 \\
\hline G-8 & 80.29 & 460.43 & 4.377 & 0 & 0 & 0 & 0 & 7 & 0 \\
\hline G-9\# & 97.08 & 421.44 & 2.593 & 0 & 0 & 0 & 1 & 6 & 0 \\
\hline G-10\# & 83.09 & 497.54 & 5.23 & 0 & 1 & 0 & 1 & 6 & 1 \\
\hline G-12\# & 83.09 & 477.55 & 4.047 & 0 & 1 & 0 & 1 & 6 & 0 \\
\hline G-13\# & 110.78 & 587.62 & 3.763 & 0 & 1 & 0 & 1 & 9 & 1 \\
\hline
\end{tabular}

\# indicate QSAR based predicted active gallic acid derivatives. 


\section{Computational parameters of pharmacokinetics (ADME) studies}

\begin{tabular}{|c|c|c|c|c|c|c|c|c|}
\hline Principal Descriptors: & Levamisol & G-3 & G-4\# & G-5 & G-6 & G-7\# & G-10\# & Stand. Range* \\
\hline $\log \mathrm{S}$ for aqueous solubility & -3.476 & -5.549 & -5.378 & -4.425 & -5.598 & -5.297 & -7.594 & $(-6.5 / 0.5)$ \\
\hline log Khsa Serum Protein Binding & 0.112 & 0.266 & 0.319 & -0.004 & 0.394 & -0.020 & 0.964 & $(-1.5 / 1.5)$ \\
\hline $\log$ BB for brain/blood & 0.462 & -1.546 & -0.924 & -1.240 & -0.923 & -1.526 & -1.023 & $(-3.0 / 1.2)$ \\
\hline No. of metabolic reactions & 2 & 5 & 5 & 5 & 5 & 5 & 6 & $(1.0 / 8.0)$ \\
\hline Predicted CNS Activity & +2 & -2 & -1 & -2 & -1 & -2 & -2 & $\begin{array}{l}-2 \text { (inactive), } \\
+2 \text { (active) }\end{array}$ \\
\hline $\begin{array}{l}\text { Log IC50 for HERG K+ Channel } \\
\text { Blockage }\end{array}$ & -4.198 & -4.306 & -6.116 & -3.717 & -6.193 & -6.721 & -7.702 & (concern below -5) \\
\hline Apparent Caco-2 Permeability $(\mathrm{nm} / \mathrm{sec})$ & 5589 & 99 & 1448 & 131 & 1682 & 597 & 1580 & $\begin{array}{l}(<25 \text { poor, }>500 \\
\text { great })\end{array}$ \\
\hline Apparent MDCK Permeability $(\mathrm{nm} / \mathrm{sec})$ & 5839 & 51 & 738 & 70 & $867 \mathrm{M}$ & $283 \mathrm{M}$ & $811 \mathrm{M}$ & $\begin{array}{l}(<25 \text { poor, }>500 \\
\text { great })\end{array}$ \\
\hline $\log \mathrm{Kp}$ for skin permeability & -3.392 & -2.469 & -1.425 & -2.377 & -1.210 & -1.971 & -0.482 & $\begin{array}{l}(-8.0 \text { to }-1.0, \mathrm{Kp} \text { in } \\
\mathrm{cm} / \mathrm{hr})\end{array}$ \\
\hline $\mathrm{Jm}$, max transdermal transport rate & 0.028 & 0.004 & 0.067 & 0.063 & 0.068 & 0.024 & 0.004 & $\begin{array}{l}\text { (micrograms } / \mathrm{cm}^{\wedge} 2- \\
\mathrm{hr})\end{array}$ \\
\hline Jorgensen Rule of 3 Violations & 0 & 0 & 0 & 0 & 0 & 0 & 1 & (maximum is 3 ) \\
\hline$\%$ Human Oral Absorption in GI (+-20\%) & 100 & 89 & 100 & 87 & 100 & 100 & 89 & $(<25 \%$ is poor $)$ \\
\hline Qual. Model for Human Oral Absorption & HIGH & HIGH & HIGH & HIGH & HIGH & HIGH & Low & (>80\% is high) \\
\hline
\end{tabular}

\# indicate QSAR based predicted active gallic acid derivatives 


\section{Compliance of active gallic acid derivatives to computational toxicity risks parameters}

\begin{tabular}{|l|l|l|l|l|l|l|l|l|l|}
\hline \multirow{2}{*}{ Compound } & \multicolumn{5}{|c|}{ Toxicity risk parameters } & \multicolumn{5}{c|}{ Drug likeness parameters (Osiris) } \\
\cline { 2 - 10 } & MUT & TUMO & IRRI & REP & MW & CLP & S & DL & DS \\
\hline Levamisol & No risk & No risk & No risk & No risk & 206 & 1.38 & -1.52 & 3.73 & 0.95 \\
\hline G-3 & $\begin{array}{l}\text { Medium } \\
\text { risk }\end{array}$ & No risk & High risk & No risk & 422 & 3.67 & -5.48 & 4.81 & 0.25 \\
\hline G-4\# & $\begin{array}{l}\text { Medium } \\
\text { risk }\end{array}$ & No risk & No risk & No risk & 424 & 3.99 & -5.6 & 0.24 & 0.31 \\
\hline G-5 & $\begin{array}{l}\text { Medium } \\
\text { risk }\end{array}$ & No risk & No risk & No risk & 396 & 3.1 & -5.17 & 4.21 & 0.48 \\
\hline G-6 & $\begin{array}{l}\text { Medium } \\
\text { risk }\end{array}$ & No risk & $\begin{array}{l}\text { Medium } \\
\text { risk }\end{array}$ & No risk & 438 & 4.45 & -5.87 & -6.57 & 0.14 \\
\hline G-7\# & risk & No risk & No risk & No risk & 452 & 3.35 & -5.52 & -10.7 & 0.21 \\
\hline G-9\# & $\begin{array}{l}\text { Medium } \\
\text { risk }\end{array}$ & No risk & High risk & No risk & 421 & 3.13 & -5.56 & 3.35 & 0.26 \\
\hline G-10\# & $\begin{array}{l}\text { Medium } \\
\text { risk }\end{array}$ & No risk & High risk & No risk & 497 & 5.23 & -6.98 & 2.55 & 0.14 \\
\hline G-12\# & $\begin{array}{l}\text { Medium } \\
\text { risk }\end{array}$ & No risk & High risk & No risk & 477 & 5.01 & -6.31 & 2.42 & 0.16 \\
\hline G-13\# & $\begin{array}{l}\text { Medium } \\
\text { risk }\end{array}$ & No risk & High risk & No risk & 587 & 4.92 & -7.03 & 4.23 & 0.13 \\
\hline
\end{tabular}

\# indicate QSAR based predicted active gallic acid derivatives 
QSAR model for cytotoxic activity against lungs cancer cell line (A-549)

$>$ Prepared a library for lung cancer cell line (A-549)

$>$ Minimized all the molecules and calculate the descriptors for regression analyses

$>$ Developed the mathematical multiple linear regression QSAR model for anticancer activity 


\section{QSAR studies}

$=-0.125338^{\star} \mathrm{J}-0.00353339^{*} \mathrm{P}-0.405538^{\star} \mathrm{S}+0.459862^{*} \mathrm{~W}-0.00475691^{*} \mathrm{~A}+0.128408^{*} \mathrm{AJ}-0.151969$

$r^{2}=0.90$

$\mathrm{rCV}^{2}=0.80$

Predicted $\log \mathbf{I C}_{\mathbf{5 0}}(\operatorname{microM})==-0.125338 *$ Dipole Moment (debye)

$-0.00353339 *$ Steric Energy (kcal/mole)

$-0.405538 *$ HOMO Energy $(\mathrm{eV})$

$+0.459862 *$ LUMO Energy $(\mathrm{eV})$

$-0.00475691 *$ Solvent Accessibility Surface Area $(\hat{\mathrm{A}})$

$+0.128408 *$ Group Count (hydroxyl)

$-0.151969$

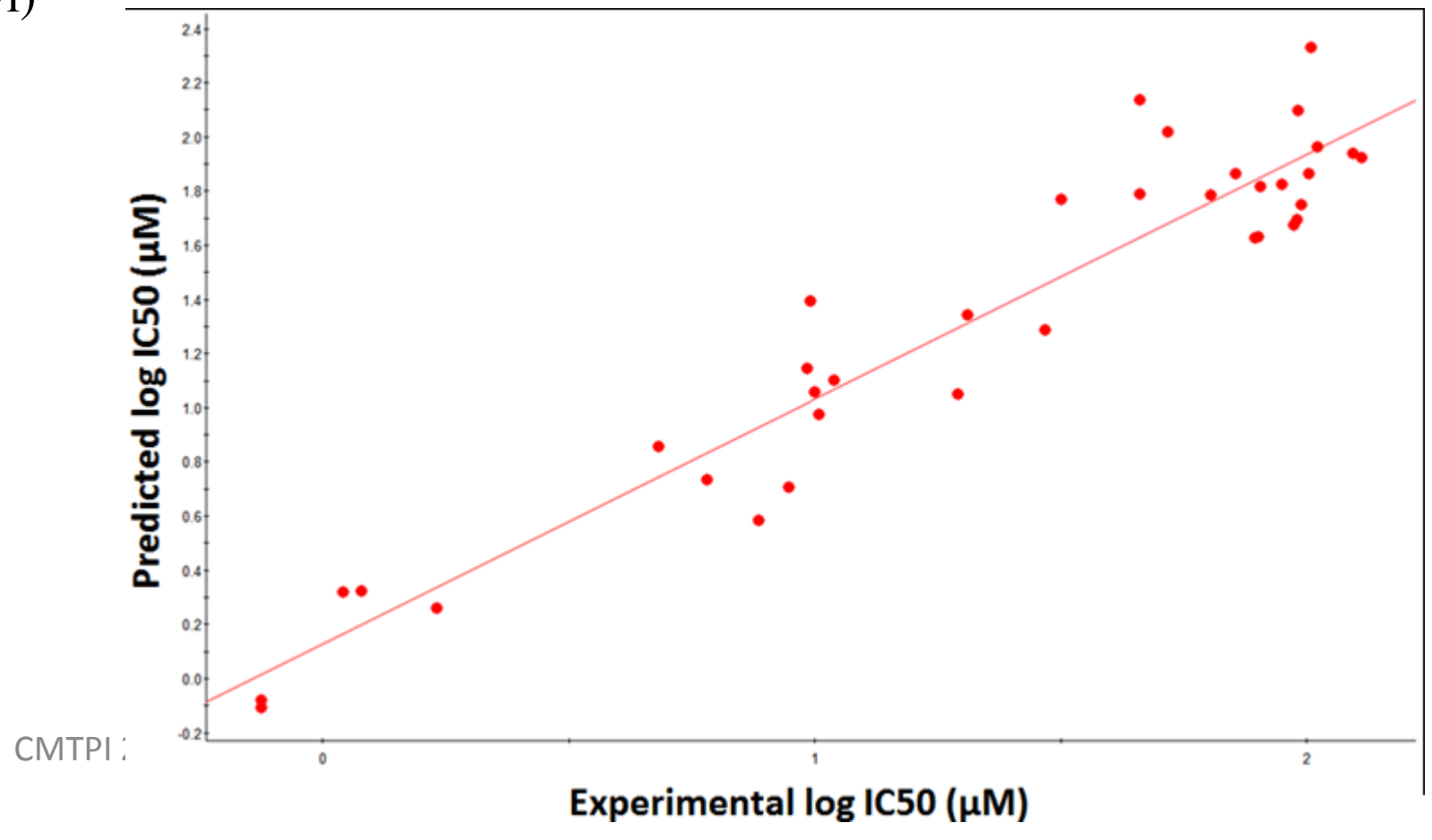




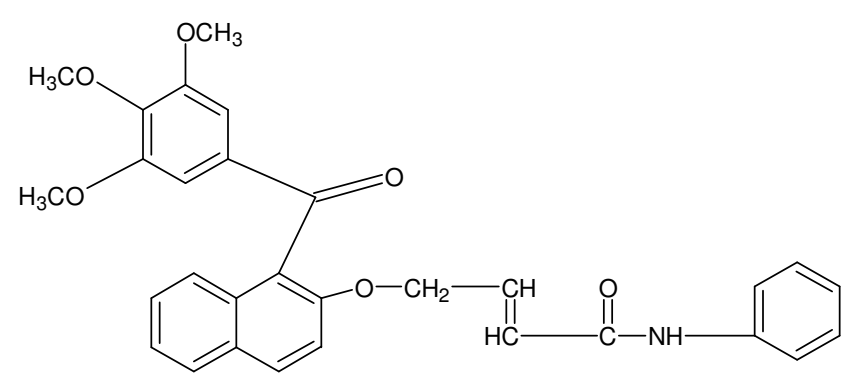

G-10 (Pred. IC50= $0.71 \mu \mathrm{M})$

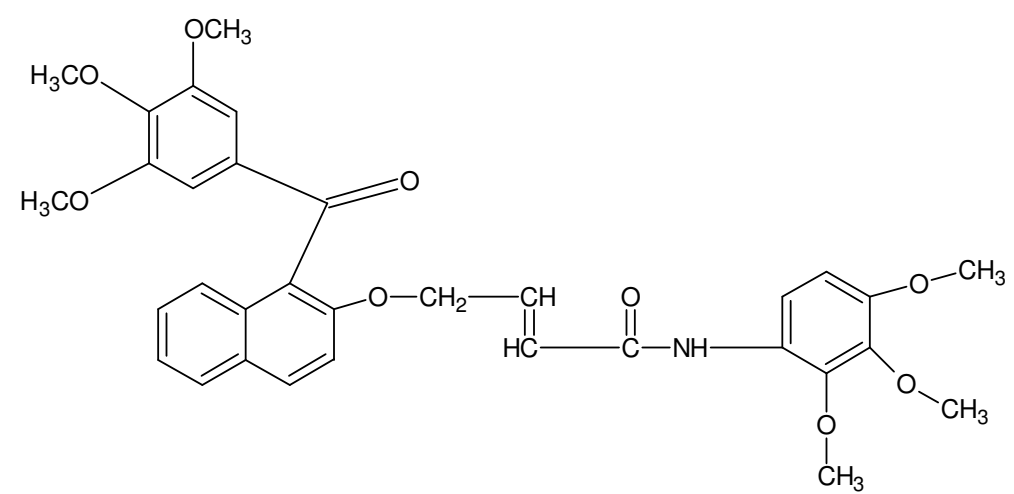

G-13 (Pred. IC50 = $0.55 \mu \mathrm{M}$ )

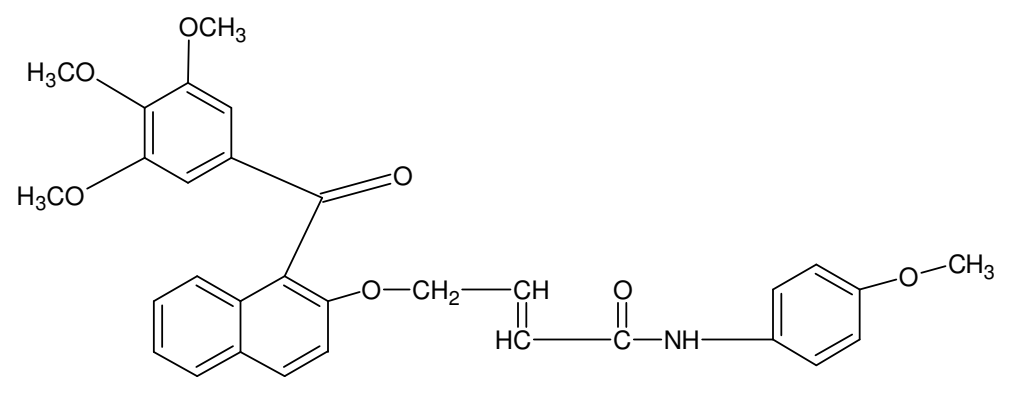

G-11 (Pred. IC50= $0.77 \mu \mathrm{M})$

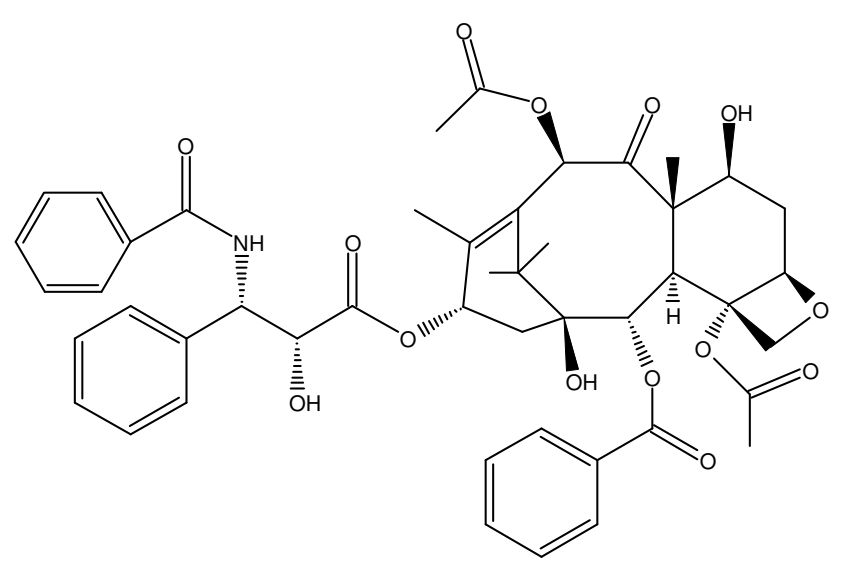

Paclitaxel (Exp. IC50 $=-1.824 \mu \mathrm{M}$ (control)

Doxorubicin (Exp. IC50=-0.125 AMMTPI 2011, Serptember 3-7, 2011 Maribor, Slovenia (control) 
- Binding site residues of INFa-2 indicate $\mathrm{H}$-bond formation with compounds G-4, G-7 and G-10

- Compounds G-5 and G-10 form the H-bond with IL-6 binding site residues

- Binding site residues of IL-4 indicate H-bond formation with compounds $\mathrm{G}-5$, and G-7, thus considered more stable and potent.

- Results of anticancer QSAR showed that compounds G-10, G-11 and G-13 have higher anticancer (against lung cancer cell line A-549) activity comparable to Doxorubicin 


\section{In Silico Exploration of Anti-Inflammatory Activity of Natural Coumarinolignoids}

\author{
Abha Meena ${ }^{1}$, Dharmendra K. Yadav ${ }^{1}$, \\ Ankit Srivastava ${ }^{1}$, Feroz Khan ${ }^{1, *}$, \\ Debabrata Chanda ${ }^{2}$ and \\ Sunil K. Chattopadhyay ${ }^{3}$
}

${ }^{1}$ Metabolic and Structural Biology Department, Council of Scientific and Industrial Research, Lucknow 226015, India

${ }^{2}$ Molecular Bio-Prospection Department, Council of Scientific and Industrial Research, Lucknow 226015, India

${ }^{3}$ Process Chemistry and Chemical Engineering Department, Central Institute of Medicinal and Aromatic Plants, Council of Scientific and Industrial Research, Lucknow-226015, India

${ }^{*}$ Corresponding author: Dr. Feroz Khan, f.khan@cimap.res.in
Key words: anti-inflammatory activity, Cleome viscosa, Coumarinolignoids, COX-2 inhibitor, molecular docking, QSAR

Received 21 January 2010, revised 6 May 2011 and accepted for publication 29 June 2011

Cleomiscosins A, B and C are the natural coumarinolignoids extracted from systemic analysis of an annual herb Cleome viscosa (syn. C. icosandra), a common weed of the family Capparidaceae, found throughout the tropical regions of the world. The plant finds use in the traditional systems of Indian medicine. Considerable phytochemical works on different parts of this plant have been reported [1.2]. These are newly identified class of nat- 


\section{Multiple linear regression analysis of anti-inflamtary activity}

$C=+0.207651{ }^{*} L-0.0872917{ }^{*} M+0.0150386 * Q+0.102653{ }^{\star} Z+1.26128 * A E+0.563956 \times{ }^{*} A F-0.724896 * A M-7.41586$

$\mathrm{r}^{2}=0.91$

$\mathrm{rCV}^{2}=0.86$

Predicted $\operatorname{logLD} \mathbf{D}_{\mathbf{5 0}}(\mathbf{m g} / \mathbf{k g})=+0.207651 \times$ Dipole Vector X (debye) $(\mathrm{L})$

-0.0872917 x Dipole Vector Y (debye) (M)

$+0.0150386 \times$ Steric Energy $(\mathrm{kcal} / \mathrm{mole})(\mathrm{Q})$

+0.102653 x LUMO Energy $(\mathrm{eV})(\mathrm{Z})$

$+1.26128 \times$ Size of Smallest Ring (AE)

+0.563956 x Size of Largest Ring (AF)

-0.724896 x Group Count (carboxyl) (AM)

$-7.41586$

$\left[\mathrm{rCV}^{2}=0.867314\right.$ and $\left.\mathrm{r}^{2}=0.918119\right]$

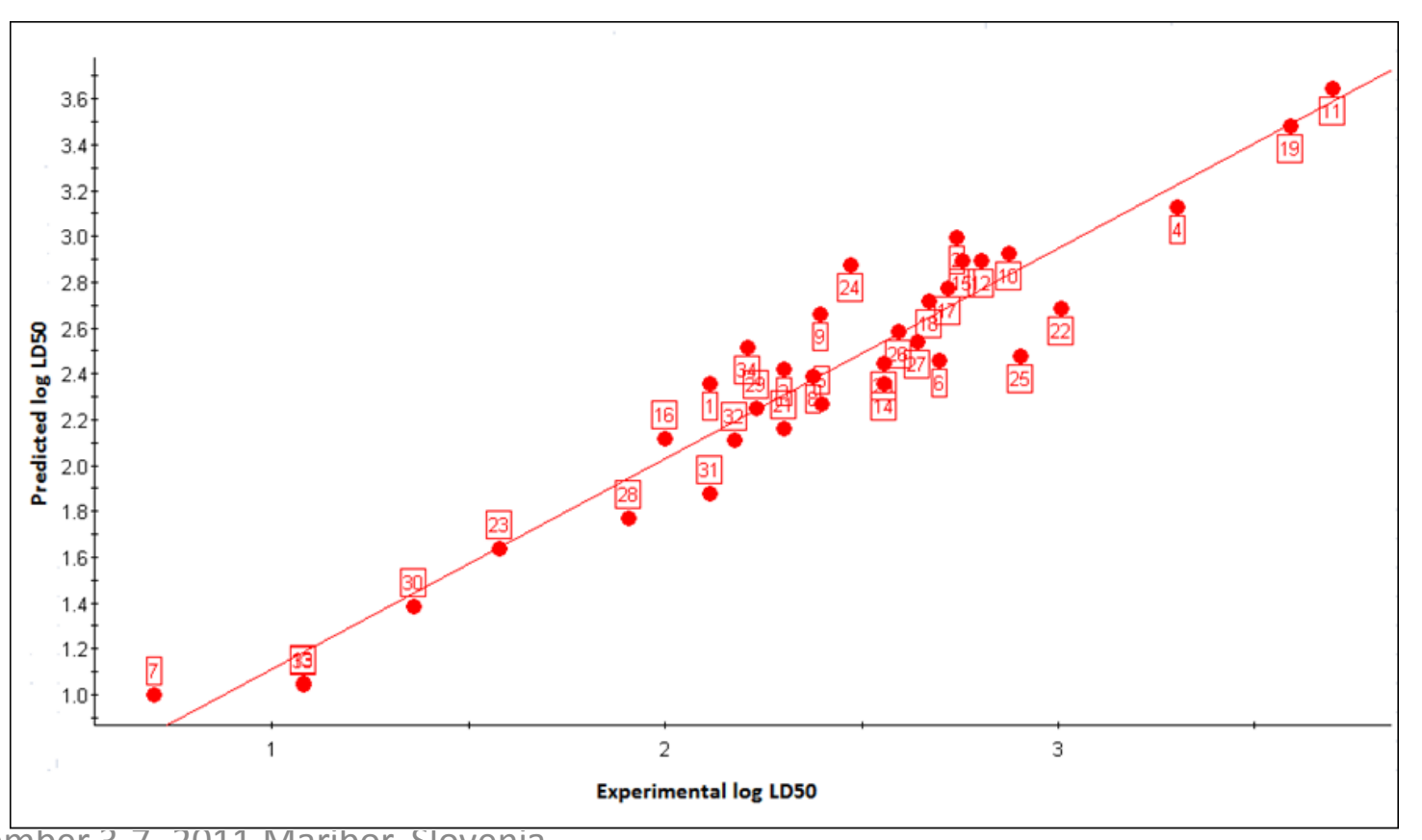


Molecular structure of the natural coumarinolignoids showing fusion of coumarin moiety with the phenylpropanoid unit (lignan) and superimposition of most favourable conformations of Clev A, Cliv B, Cliv C and diclofenac docked on Interferon alpha-2

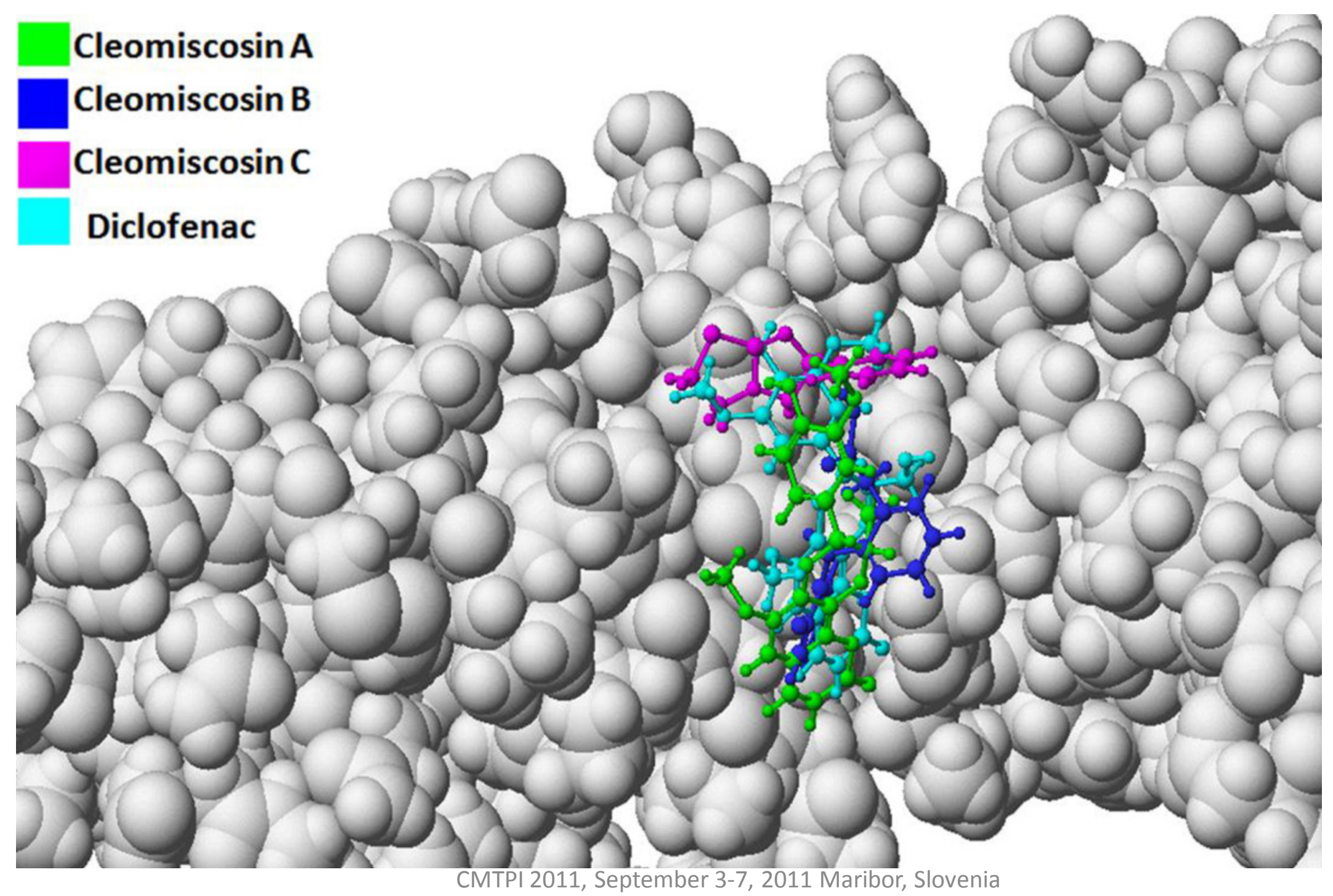




\title{
Modern Methods \& Web Resources in Drug Design \& Discovery
}

\author{
Feroz Khan ${ }^{1}$, Dharmendra Kumar Yadav ${ }^{1}$, Anupam Maurya ${ }^{2}$, Sonia ${ }^{2}$ and \\ Santosh Kumar Srivastava*,2 \\ ${ }^{1}$ Metabolic \& Structural Biology Department; ${ }^{2}$ Analytical Chemistry Division, Central Institute of Medicinal \& \\ Aromatic Plants, (Council of Scientific \& Industrial Research), Lucknow-226015 (U.P.), India
}

Received December 22, 2010: Revised February 25, 2011: Accepted March 03, 2011

\begin{abstract}
Traditionally, the process of drug development has revolved around a screening approach and trial-and-error method, as no body knew which compound or approach could serve as a drug or therapy. This discovery process was very time consuming and laborious and discovery of a new drug used to take around 8-14 years and costs about US \$1.8 billion. In order to minimize the time and cost in this drug discovery process, scientists around the world contributed tremendously and come up with a modern drug-designing program. The beauty of this modern drug designing is that now we

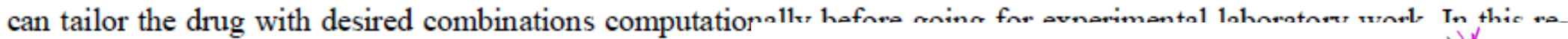
view, traditional to modern methods of drug designing ، tools/databases and in silico techniques used in virtual scri omy and time. Studies suggest that the best method for $\mathrm{m}$ of various types of algorithm encompassing novel search etc. However, apart from in vitro assays and in vivo exper tion of biological activity \& bioavailability are proving ber

Keywords: Drug design, Drug discovery, QSAR, Lead identifi

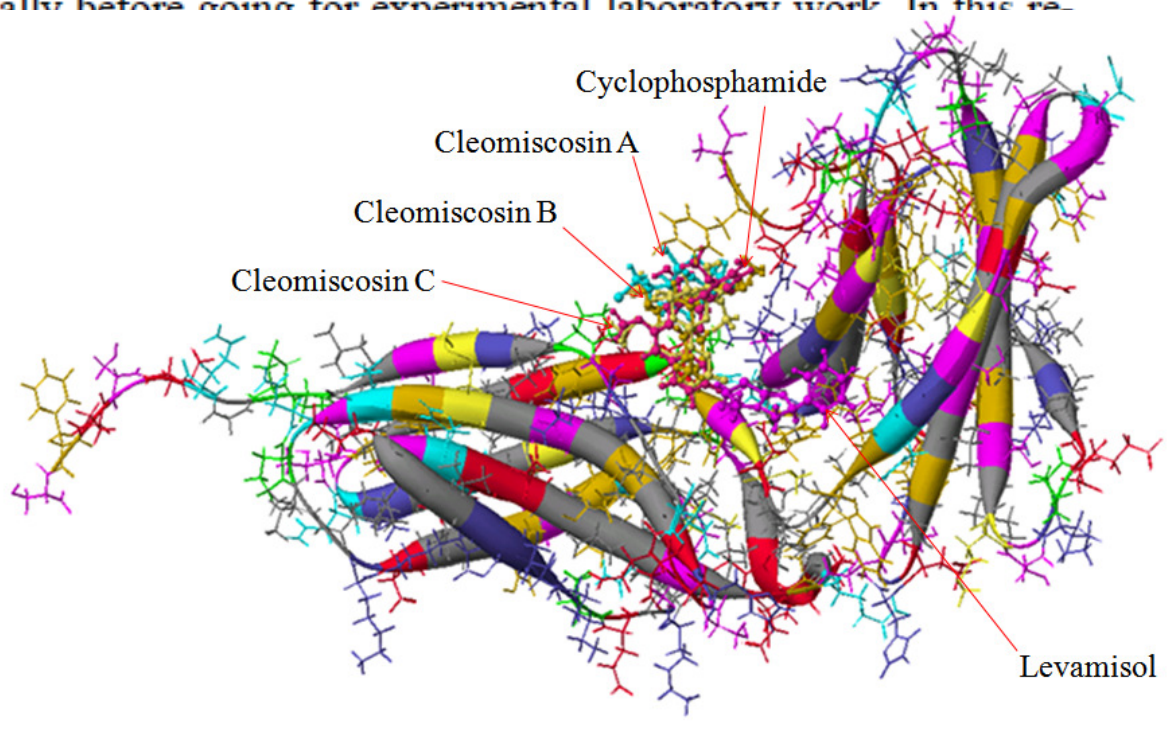




\title{
Development of QSAR model for immunomodulatory activity of natural coumarinolignoids
}

\author{
This article was published in the following Dove Press journal: \\ Drug Design, Development and Therapy \\ 29 July 2010 \\ Number of times this article has been viewed
}

Dharmendra K Yadav

Abha Meena

Ankit Srivastava

D Chanda

Feroz Khan

SK Chattopadhyay

Metabolic and Structural Biology Department, Central Institute of

Medicinal and Aromatic Plants,

Council of Scientific and Industrial Research, PO-CIMAP, India

\begin{abstract}
Immunomodulation is the process of alteration in immune response due to foreign intrusion of molecules inside the body. Along with the available drugs, a large number of herbal drugs are promoted in traditional Indian treatments, for their immunomodulating activity. Natural coumarinolignoids isolated from the seeds of Cleome viscose have been recognized as having hepatoprotective action and have recently been tested preclinically for their immunomodulatory activity affecting both cell-mediated and humoral immune response. To explore the immunomodulatory compound from derivatives of coumarinolignoids, a quantitative structure activity relationship (QSAR) and molecular docking studies were performed. Theoretical results are in accord with the in vivo experimental data studied on Swiss albino mice. Immunostimulatory activity was predicted through QSAR model, developed by forward feed multiple linear regression method with leave-one-out approach. Relationship correlating measure of QSAR model was $99 \%\left(R^{2}=0.99\right)$ and predictive accuracy was $96 \%\left(\mathrm{RCV}^{2}=0.96\right)$. QSAR studies indicate that dipole moment, steric energy, amide group count, lambda max (UV-visible), and molar refractivity correlates well with biological activity, while decrease in dipole moment, steric energy, and molar refractivity has negative correlation. Docking studies also showed strong binding affinity to immunomodulatory receptors.
\end{abstract}

Keywords: coumarinolignoids, immunomodulation, docking, QSAR, regression model 


\section{Binding affinity of Cleomiscosin A, B and C against Toll like Receptors}

(TLR's)

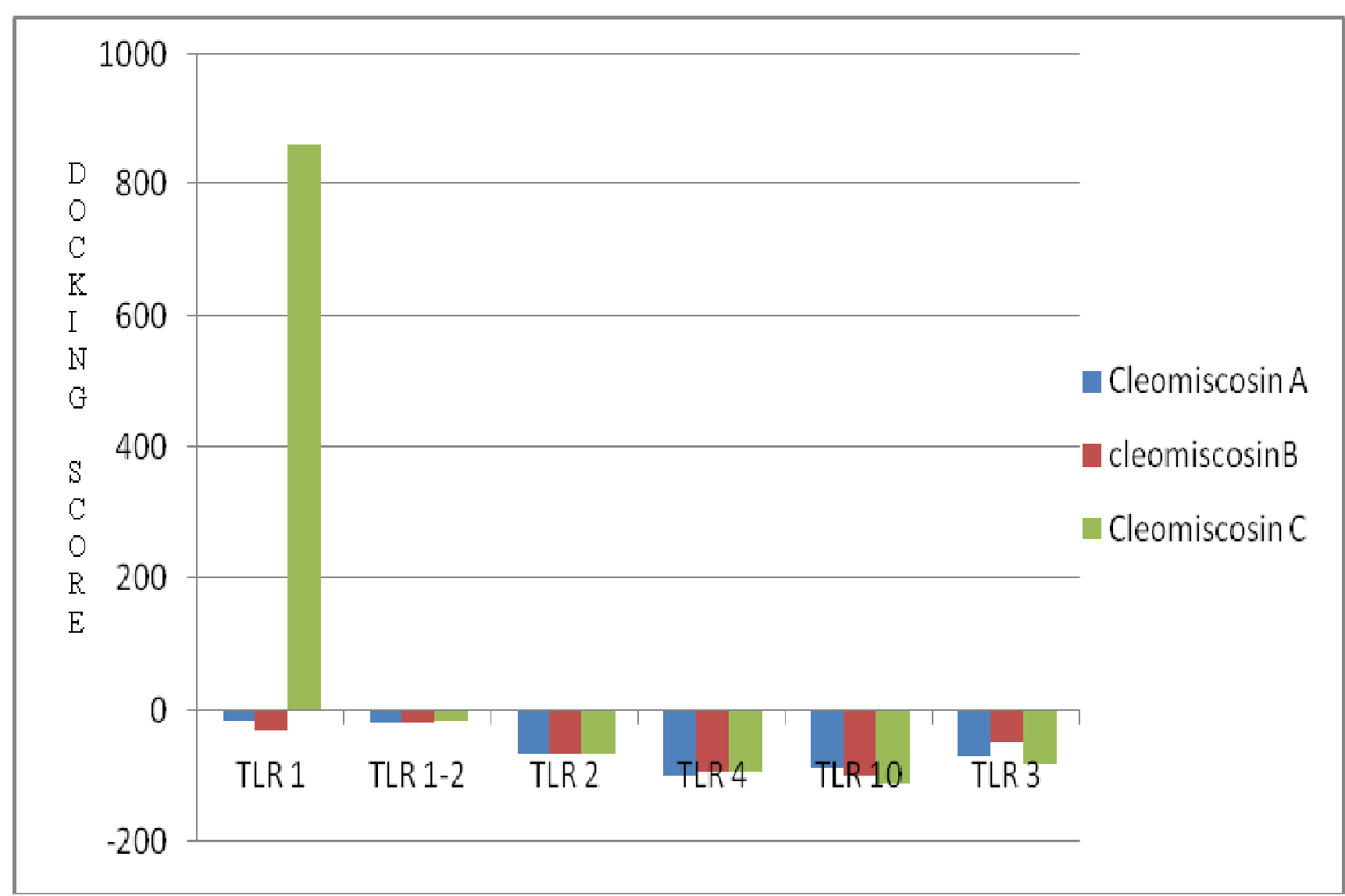

CMTPI 2011, September 3-7, 2011 Maribor, Slovenia 


\section{Binding affinity of Cleomiscosin $\mathrm{A}, \mathrm{B}$ and $\mathrm{C}$ with various Cluster of Differentiation molecules (CD's)}

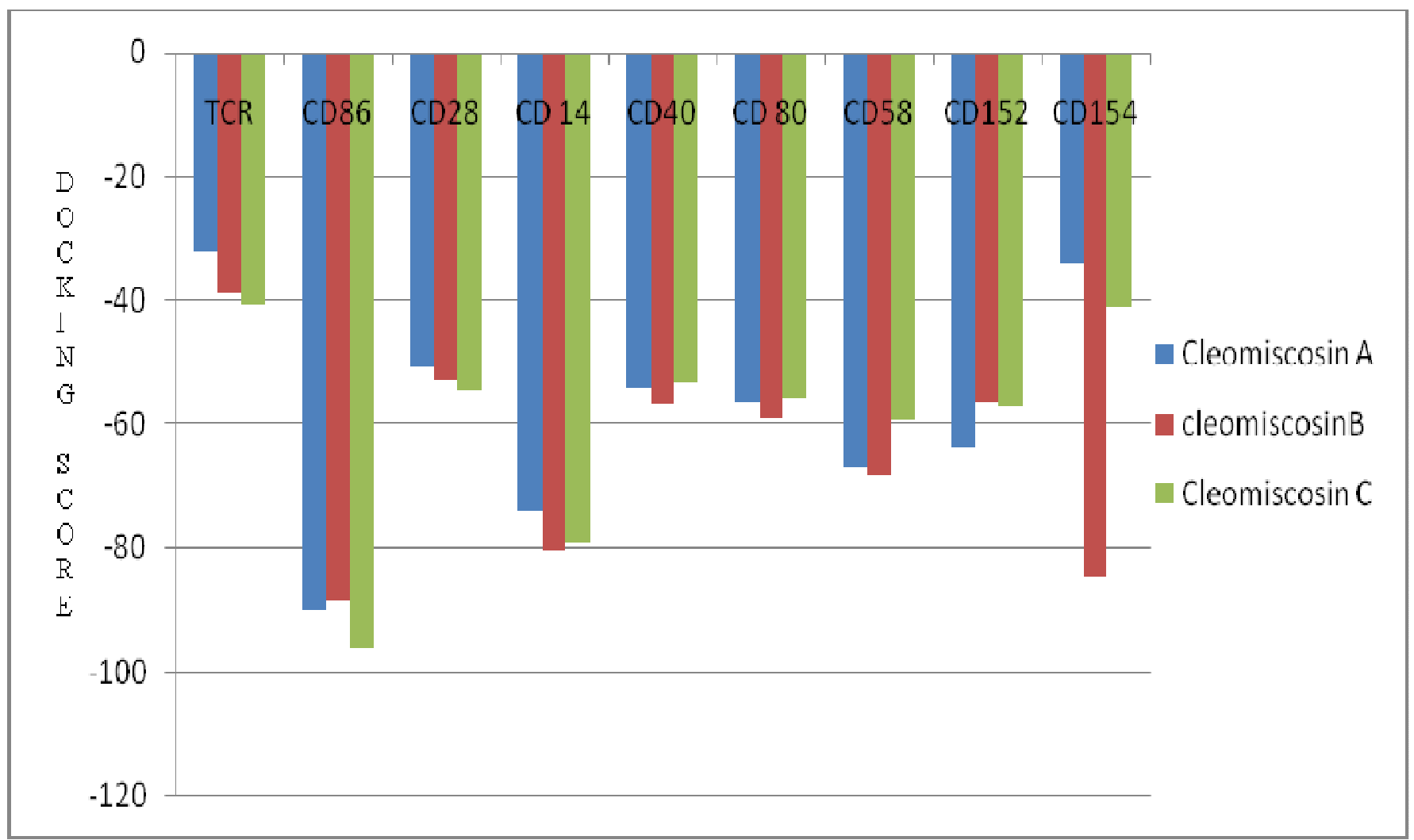




\section{Binding affinity of Cleomiscosin A, B and C with various immune reaction cascade proteins and inducible nitric oxide synthase protein}

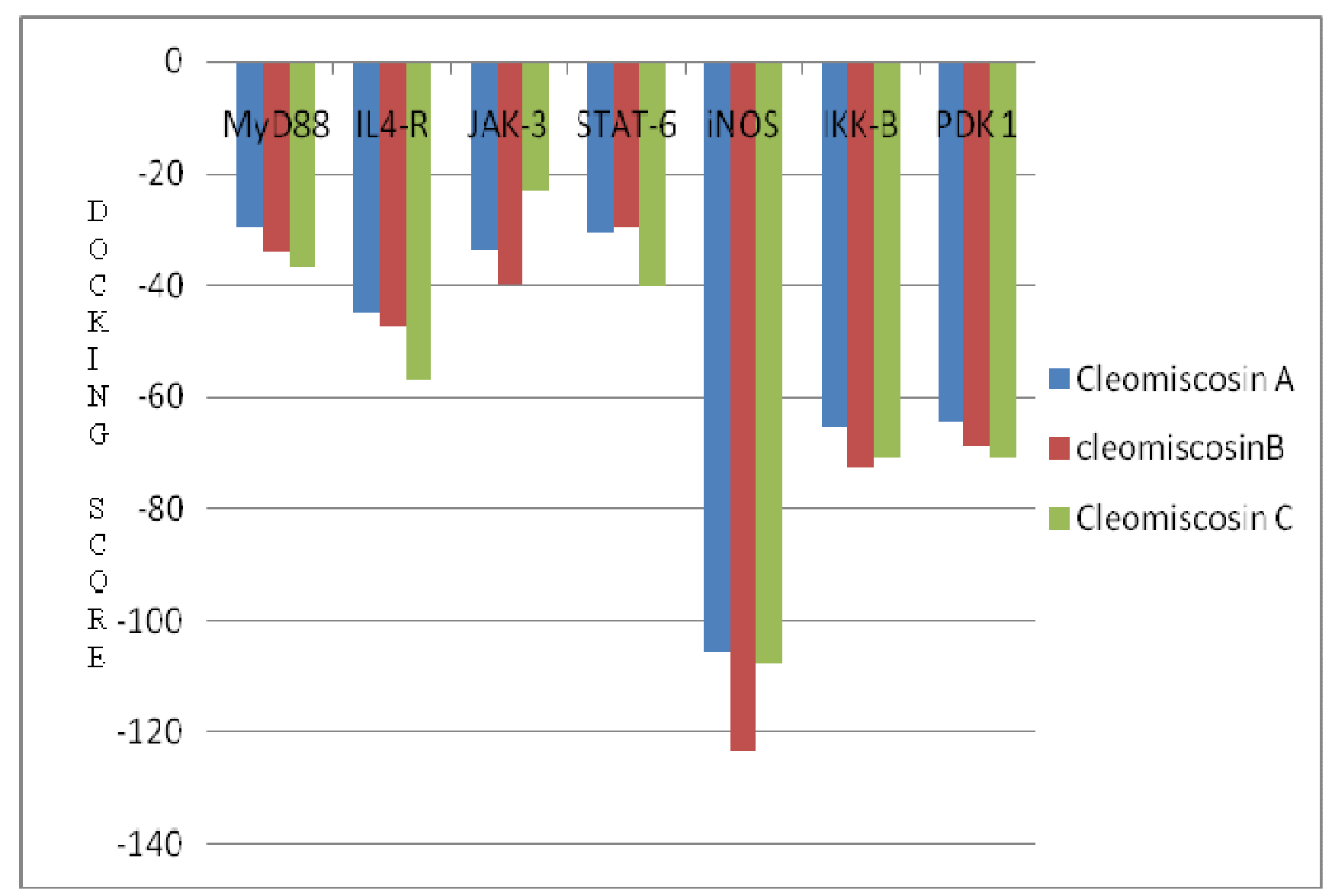

CMTPI 2011, September 3-7, 2011 Maribor, Slovenia 


\section{Molecular docking based identification of potential immuno- modulatory targets of cleomiscosin molecules}

\begin{tabular}{|l|l|}
\hline Coumarinolignoids & Potential Target \\
\hline Cleomiscosin A (1a) & TLR-4 \\
\hline Cleomiscosin B (2a) & iNOS, COX-2, CD14, IKK B \\
\hline Cleomiscosin C (1f) & CD86, COX-1 \\
\hline
\end{tabular}




\section{Thanks for your attention !!}

